УДК 130.31

DOI: $10.17223 / 1998863 X / 38 / 32$

\title{
А.С. Тимощук
}

\author{
РЕЦЕНЗИЯ \\ НА КНИГУ КУТЫРЁВА В.А. \\ «ПОСЛЕДНЕЕ ЦЕЛОВАНИЕ. ЧЕЛОВЕК КАК ТРАДИЦИЯ». - \\ СПБ.: АЛЕТЕЙЯ, 2015. - 312 С. - (СЕРИЯ «ТЕЛА МЫСЛИ»)
}

\begin{abstract}
Владимир Александрович Кутырёв известен как философ-алармист, сторонник управляемого прогресса. Его статьи и книги - это событие для российской интеллектуальной жизни. Его читают, ичитируют, публикуют. Издания Кутырёва отличает сплав высокого гуманизма и пространной эрудиции профессионального философа, яркий художественный стиль, делающие каждую его книгу привлекательной для широкой аудитории

Ключевые слова: гуманизм, коэволюция, консерватизм, технологические предель.
\end{abstract}

Новые публикации В.А. Кутырёва - всегда заметное явление в российской интеллектуальной жизни. Его труды отличает сплав высокого гуманизма и пространной эрудиции профессионального философа, яркий художественный стиль, делающие каждую его книгу привлекательной для широкой аудитории. «Последнее целование. Человек как традиция» выделяется ещё и кросскультурной тематикой.

Привычно Владимир Александрович предостерегает читателя от деградации, критикуя постмодернизм/трансмодерн, и раскрывает смысл истории как традицию человека. Конец истории усматривается ещё у Парменида и Канта, положивших начало когнитизации реальности. Если отвлечься от трагической диалектики истории, то обосновывается вполне здравая мысль - не все, что технически возможно, следует воплощать в жизнь. Этический контроль должны осуществлять философы, а для самых буйных учёных может существовать игровая наука, атомные бомбы и адронный коллайдер как музейные экспонаты (С. 17).

Подобно тому, как мы не торопимся к смерти в индивидуальной жизни, такой должна быть модель поведения родового человека - жить, смеяться и верить, как дети и влюбленные.

Несомненным достоинством книги является глубинное погружение в каждую обозначенную проблему. Нижегородский философ докапывается до самых оснований когнитивной науки: Гоббс - Буль - Тьюринг - computer science; никто не уходит от внимания консервативного романтика, даже «популярный у молодёжи Фредерик Бегбедер.

В первой части «ИНАЯ РЕАЛЬНОСТЬ» автор критикует замещение метафизической философии позитивизмом. Владимир Александрович фиксирует весьма тонкие модификации замены гносеологии с традиционными вопросами соотношения субъекта и объекта эпистемологией, теорией и методологией науки. Он полагает, что имеет место радикальный когнити- 
визм или редукция всего многообразия философского знания к теме научного познания.

Подтверждает он свои утверждения анализом современных философских текстов, содержания новых философских энциклопедий, откуда изымаются традиционные ранее философские категории - человек, субъект, объект. Вместо этого - смерть Бога, эстетика пустоты, складки зла и территории перверсий. Цивилизация, заигрывающая со смертью, провозглашающая идеологию самоубийства и глумления над жизнью, в прямом смысле призывает апокалипсис.

В.А. Кутырёв предлагает самобытную интерпретацию истории философии Лейбница, Канта, Гегеля, Гуссерля, Витгенштейна, Хайдеггера сквозь призму вопросов познаваемости мира и укоренённости человека в бытии.

Позитивный итог первой части суммируется в максиме - сначала надо быть, а потом меняться; развиваться надо для того, чтобы быть. Sustainable development - это когда изменение и становление не самоцен(ль)ны, не движение в дурную бесконечность, а служат сущему и Бытию (С. 85). Для философии же в качестве диеты и здорового моциона Кутырёв прописывает диалектико-феноменолого-синергетическую методологию.

Часть вторая, «ЧЕЛОВЕК ХХІ: УХОДЯЩАЯ НАТУРА, УГАСАЮЩИЙ ДУХ...», начинается с итерации известных прогрессистских штампов перехода от первобытного состояния к сапиентному. Жаль, что критицизма Кутырёва не хватило на редукцию этой затёртой и эмпирически не проверенной мифологемы. Культура, личность, духовность предстают здесь как банальные эволюционные исторические завоевания, достигнутые за тысячелетия дикости и варварства.

Следом идёт ещё одна мифологема. После скачка к целерациональному действию Вебера в качестве гипертрофированного примера приводятся слова немецкого социолога, обличающие стремление к наживе в США - «бездушные профессионалы, бессердечные сластолюбцы» (С. 91). Увы, антиамериканизм наших неоконсервативных интеллектуалов носит книжный и оценочный характер. Дальнейшие рассуждения о становлении Акторатехнократа взамен обычного человека - готовый конспект для выступления в молодёжном лагере на Селигере.

Кутырёв порицает замену человека архаического личностью динамической, рыночной и либеральной, отрицающей добуржуазную историю, историю Советского Союза. Это, действительно, свежий взгляд на историю! Особенно, если мы вернёмся вновь на фундаментальное основание неизменности человека в истории.

Злословие по поводу электронного человека, как всегда у Владимира Александровича, очёнь хлёсткое и метафоричное. Здесь и «ручной или виртуально-технический аутизм человека-фактора, потерявшего интерес к сексу», «роль человека как поставщика эмпирического материала», «мыслящий зомби», «воля к потреблению», «кремниевое бессмертие», «неомания», «словесные “консервы” хранятся неопределенно долго», «Деррида, Делёз, операторы по клинингу», «культура смерти» и пр.

Пафос по поводу наступления космо-электро-кибер эры настолько велик, что по прочтении книги складывается впечатление, что мы живём в стране 
из сценария Джорджа Лукаса, а не в обществе, где часть населения пользуется уличным туалетом, дровяным отоплением и все NBICS технологии рухнут перед традиционностью 6-миллиардного Третьего мира. Информационно-космические технологии остаются лишь тонкой ширмой, за которой проглядывают Средневековье и варварство. Наш технологический прорыв до транзисторов - это лишь кратковременное упущение метеоритного пояса Койпера.

Книги Кутырёва всегда заманчивы онтопоэтическим рифмачеством. В духе Хайдеггера он делает неожиданные переходы и аллюзии: точная наука: точка тычка - тычинка и пестики - мужское и женское; на(ви)сельники виртуальной реальности; тело: тло, зола, земля, глина, прах, вещество, вещ(ит), весит, телец, теленок, тяжесть, при-тяжение (тела к телу) в космосе и жизни; кожа: кожура, кора, корки, корень, шкора, шкура, с(ш)корняки, скуратовы, кожаное пальто или сапоги; уд^ удалец,...(м)удило, Лука Мудищев, ....ударник (винтовки, труда), (м)удак, (м-удо)звон, бл-уд-ница...заблуждение, удо-вольствие, удовлетворение,... буй-тур, горный козел, турнир ...турак, дурак... (С. 35, 306)

Справедлива критика технократического романтизма Вернадского и Циолковского. Представления о ноосфере как научном рае, где будут горы хлеба и бездны могущества, оказались поверхностны и несбыточны. Согласен с автором, что никакие действительные тенденции эту счастливую надежду не подтверждают. Напротив, наблюдается достижение технических пределов в космосе, а это означает переориентацию инженерной мысли с экстерналистской программы на интерналистскую по энергосбережению и устойчивому развитию на Земле. Именно поэтому книги В.А. Кутырёва чрезвычайно нужны сегодня для гуманистического и гуманитарного образования, противостоящего наивному технократизму. В России чрезвычайно востребована программа сбалансированного подхода к хозяйствованию и инновациям. Гонка за водой на Марсе не должна перевешивать заботу о собственных водных и лесных ресурсах. Особенно в условиях дефицита бюджета.

Заключительная третья часть «В КОНЦЕ БЫЛА ЦИФРА...» посвящена критике выхода из плена языка и увяданию традиционной сигнальной системы. Кутырёв ратует за возврат влияния языковой философии и артикулирование смыслов христологической цивилизации.

Делается обзор современных контрлингвистических революционеров. Разгромлена философия языка А.С. Нилогова, ибо есть веер противоречивых предположений и утверждений во главе с главным оксюмороном - для того чтобы повысить культуру молчания в нашей стране, необходимо высказаться на 216 страницах. Кутырёв полагает, что автор подменяет антиязык невербальной коммуникацией, медитацией, бессознательным.

Bсе, кто сидит за компьютерами, заняты, в сущности, скрипторикой. 3-D принтеры сделают мир письмом! Творить - значит печатать. Автоматы, печатающие сами себя. Скрипторика как идеология пишущего класса. «"Глухие демоны”, т. е. самоуправляемые компьютерные программы будут беседовать друг с другом вообще “без мозгов”» (C. 257-260). 
Осуждена риторическая теория числа С.Е. Шилова, предлагающего перейти к восприятию физического мира без метафор (клей, супы, цветность, четность, темная материя) и призывающего вернуться к первичному элементу кодирования языка - числу: «Цифра беспредметна, поэтому лишена воображения и моделирования. Новый тип рациональности - философия электронного мышления» (С. 260-265).

Себя Кутырёв не включает в число революционеров. А надо бы! Его программа сопротивления проста в своей естественности. Радикальный поворот философии - забыть Дерриду (Нилогова? Шилова? Эпштейна?)

Заключение подводит нас к программе консервативного поворота. B.А. Кутырёв увещевает не участвовать из моды в программе умертвления и расчеловечивания мира - агенты сциентизма и техницизма, одумайтесь, не будьте слепым орудием самоапокалипсиса.

Нижегородский мыслитель артикулирует консерватизм как философию хранителей мира. Литургия, спасение, христианская проповедь противостоят либертарным заявлениям «Прогресс не остановишь», «Иного не дано», «Техника - наша судьба». Прогрессизм не должен быть поистине неотвратимым как смерть, приходит к заключению автор.

Что вместо технического поступательного развития? Звучат лозунги «исповедовать парадигму коэволюции и полионтизма», «заботиться о продлении своей, нашей, человеческой формы», «поощрять безвозвратный отлёт на Марс всех технократов и при этом бороться за сохранение живой колыбели разума», «Земля как гомопарк», «борьба за Традицию», «Всемирное Движение Человеческого Сопротивления!», «консерватизм как творческое действие по сохранению, памятованию и благодарности» (С. 268-276).

Либеральный прогрессизм - это установка на то, чтобы забыть, ссылается Кутырёв на интеллектуальный бестселлер П. Крусанова «Ворон белый. История живых существ» (СПб., 2012). Прогрессом следует управлять, соотнося с целями и благом человечества.

Книга снабжена интервью автора по поводу выхода предыдущей книги «Философия Mortido». Кутырёв даёт прямолинейные ответы на такие каверзные утверждения и предложения, как: «отечественное восприятие постмодернистской философии весьма поверхностно, а потому - крайне агрессивно», «ваша трактовка небытия носит не чёткий методологический характер, а паразитирует на волне всеобщего отрицания - того самого нигилизма, чья причина - забвение вопроса о ничто», «Ваша критика трансгуманизма однобока, а потому - непродуктивна», «посмотрите позитивно на основные положения доктрины «Бессмертие - 2045», «пора с почестями похоронить труп Человека», «прогресс / консерватизм - это старая бинарная привычка», «философия - не женское дело».

Общий вывод: книга В.А. Кутырёва, несомненно, блистательна! Такая оппозиционная философия необходима человечеству перед фактом экспансии высоких технологий. Кутырёва нужно читать уже ради того, чтобы узнать новинки литературы и получить свежий взгляд на историю философии от Парменида до А. Зиновьева.

И пускай временами автор борется с фантомами технократии, его критика эконометрического подхода к хозяйствованию, построенного на ВВП, 
потреблении и инновациях, тренда преодолеть остатки ценностного подхода к социальным проблемам вплоть до провозглашения «приоритета права над благом», справедлива и своевременна. Технократы в российском образовании уже победили! Менеджмент качества образования - чистая кибернетика, которая проверяет воспитанность и образованность студента входами, выходами, процессами и количественным методом их подсчёта.

Философия сопротивления консервативного романтизма проста и изящна - поставь жизнь выше поисков её смысла. В провозглашении глубинной экологии как заботы о предметном макромире автор в лучших традициях русской литературы превозносит Человека обыкновенного, а значит, и повседневность православной Софии.

Timoschuk Alexey S. Vladimir Law Institute FSIN of Russian Federation (Vladimir, Russian Federation)

E-mail: a@timos.elcom.ru

DOI: $10.17223 / 1998863 \mathrm{X} / 38 / 32$

REVIEW OF THE BOOK BY KUTYREV V.A. LAST KISSING. MAN AS THE TRADITION. - SPB .: ALETHEIA, 2015. - 312 P. - ("BODY OF THOUGHT" SERIES)

Key words: humanism, co-evolution, conservatism, technological limits

Every new book by V.A. Kutyrev is always a significant event in in Russian intellectual life. His works are distinguished by a high alloy of humanism and erudition, lengthy professional criticism, pungent style, all that is needed to make every new book a novelty. Customarily Vladimir warns the reader against degradation in a new, criticizing postmodernism / transmodern and reveals the meaning of history as a human tradition. The end of history is seen more in Parmenides and Kant, that ushered knowledge based understanding of reality. Apart from the tragic dialectic of history, it is proved quite a sensible idea - not everything that is technically possible, should be put into practice. Ethical control must implemented by philosophers, as for atomic bombs and Hadron Collider - they should be displayed as museum exhibits. Kutyrev's philosophy of conservative romantic resistance is simple and elegant - put the life above the quest of meaning. The proclamation of deep ecology as care about the things around us is done in the best traditions of Russian literature and Orthodox Sofia. 